\title{
TRADUZIR UMA TRADUÇÃO: ALGUMAS OBSERVAÇÕES SOBRE A TRADUÇÃO DO PRIMEIRO LIVRO DE MACABEUS
}

Translating a Translation: Notes on the Translation of First Book of the Maccabees

Leonardo Pessoa da Silva Pinto *

RESUMO: Este artigo apresenta as dificuldades e desafios para a tradução do primeiro livro de Macabeus na língua portuguesa, tendo em vista as características do grego desta obra, bem como do seu caráter de tradução de um original semítico. A tentativa de se produzir uma tradução em português seguindo o princípio da equivalência dinâmica impõe ao tradutor um constante processo de negociação quando o texto grego a ser traduzido é já uma tradução que buscou correspondência formal com o texto hebraico original. As etapas dessa negociação e as considerações do tradutor são apresentadas neste artigo através da discussão de vários exemplos.

PALAVRAS-CHAVE: Bíblia. Antigo Testamento. Exegese. Tradução. 1 Macabeus.

SUMMARY: This paper discusses the difficulties and challenges of translating the First Book of Maccabees into Portuguese, given the characteristics of the Greek text and its character as a translation of a Semitic original now lost. The attempt to produce a translation in Portuguese following the principle of dynamic equivalence required a continual process of negotiation since the Greek text (translated) is already a translation that sought formal correspondence with its Hebrew source. The steps of these negotiations and the translator's considerations are herein presented through the discussion of various cases.

KEYWORDS: Bible. Old Testament. Exegesis. Translation. 1 Maccabees.

* Pontifício Instituto Bíblico, Roma, Itália. 


\section{Introdução}

trabalho de traduzir o primeiro livro de Macabeus para a língua portuguesa impõe uma série de problemas para o potencial tradutor. Alguns se relacionam com questões gerais sobre os princípios de técnica de tradução a serem utilizados na nova tradução, em parte determinados pela editora ou projeto que a encomendou. Outros concernem a natureza mesma do livro a ser traduzido. Alguns problemas, enfim, têm a ver com desafios lançados pelos casos concretos específicos encontrados pelo tradutor ao longo do trabalho. O objetivo deste artigo é apresentar as dificuldades enfrentadas pelo tradutor de 1 Mc e o modo como chega a soluções para a tradução portuguesa. A meta não é apresentar todos os tipos de problemas encontrados, mas aqueles mais frequentes ou basilares.

Muitos colegas teólogos, leigos e mesmo estudantes que iniciam uma formação em exegese ou teologia bíblica perguntam a respeito da diversidade de traduções da Bíblia, como é possível que existam tantas traduções diferentes ou para que ainda se produzem novas traduções já que, afinal, “a Bíblia já foi traduzida para o português". Este artigo não pretende responder ou tratar todos os aspectos implicados por estas questões. Contudo, ao revelar as dificuldades e os processos decisórios enfrentados pelo tradutor, bem com os seus respectivos raciocínios para se chegar a uma solução, este artigo pode contribuir para um esclarecimento ao menos parcial para a legítima curiosidade dessas pessoas.

\section{Questões gerais}

\subsection{A natureza da tradução grega}

O primeiro livro de Macabeus é geralmente considerado uma tradução de um original semítico, provavelmente hebraico (NEUHAUS, 1974, p. 47-50; TILLY, 2016, p. 46-47). A existência de um original hebraico é mencionada já por Jerônimo em seus escritos (TILLY, 2016, p. 301). No nosso próprio trabalho e estudo do texto grego de $1 \mathrm{Mc}$, chegamos à mesma conclusão. $\mathrm{O}$ grego de 1 Macabeus é pouco idiomático e apresenta uma série de características semelhantes aos textos traduzidos em grego na Septuaginta, um grego de tradução que frequentemente reproduz fenômenos da língua hebraica. Dificilmente um autor poderia escrever a obra diretamente em grego, emulando a língua encontrada nas traduções dos livros da Bíblia Hebraica em grego. É difícil imaginar até mesmo porque alguém faria algo do gênero. Trata-se, portanto, de um grego de tradução que procura não se afastar da língua semítica original, buscando mesmo uma correspondência formal com o texto-base da tradução. Em resumo, o primeiro livro de Macabeus é uma 
tradução de um original semítico, provavelmente hebraico, perdido. Traduzir 1 Macabeus para uma língua moderna como a portuguesa é, portanto, traduzir uma tradução. $\mathrm{O}$ original hebraico, porém, não foi preservado, perdeu-se na passagem dos séculos. Este fato torna hipotético todo esforço de reconstrução do hebraico subjacente ao texto grego, mesmo quando se trata das expressões ou palavras mais recorrentes na literatura bíblica.

Numa tradução, uma questão fundamental é compreender como o texto a ser traduzido se relaciona com o sistema da língua em que foi escrito. É desejável que a tradução consiga reproduzir para o leitor do texto traduzido, em alguma medida, a experiência de leitura do leitor da língua original. Assim, um texto com uma linguagem mais alta, mais elegante, requereria uma tradução que reproduzisse o mesmo efeito utilizando um registro mais alto da língua de chegada da tradução. $O$ contrário é igualmente verdadeiro, o tradutor de textos com uma sintaxe e um estilo mais simples deveria buscar a mesma simplicidade na tradução, a fim de aproximar a experiência do leitor da tradução àquela do leitor do original.

Como 1 Macabeus é uma tradução de cunho literal, a qual gerou um texto grego pouco elegante e que soa artificial na língua de chegada, uma tradução em português que transmita a sensação do leitor grego deve buscar um registro da língua que, em conformidade, seja pouco fluido. A simplicidade e a dureza das expressões, neste caso, não são defeitos da tradução, mas um valor agregado, já que indicam uma fidelidade não apenas ao conteúdo das expressões no texto de partida, mas também ao modo como a mensagem é expressa. Assim, nos exemplos abaixo, se verá como a tradução de 1 Macabeus realizada no respeito ao princípio aqui exposto beira, às vezes, o limite do aceitável segundo as normas e usos da língua portuguesa. Beira o limite, mas procura não o transgredir. A situação curiosa que aqui se encontra é que, embora seja um princípio típico das traduções que buscam equivalência dinâmica equiparar a relação entre receptor e mensagem da tradução àquela entre receptor e mensagem do texto original (NIDA, 2003, p. 159), no caso de 1 Mc o respeito a esse princípio requererá a aplicação de equivalência formal em uma certa medida. Anos atrás, Marguerite Harl explicou como o projeto La Bible d'Alexandrie procurou reproduzir na tradução francesa os mesmos efeitos de estranheza ou incoerência gramaticais presentes na língua original, a raridade de certas construções etc. (HARL, 1993, p. 317-320). É exatamente a mesma ideia por trás da tradução portuguesa aqui proposta.

Um caso interessante se encontra em 1 Mc 2,47. Segue-se ao texto grego a tradução portuguesa:

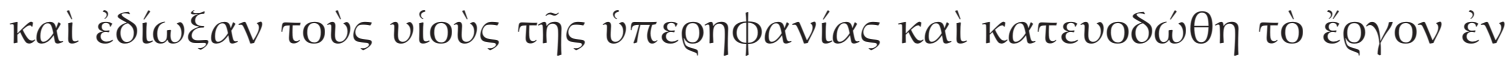

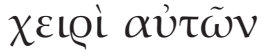

E perseguiram os filhos da arrogância; a empresa prosperou nas suas mãos. 


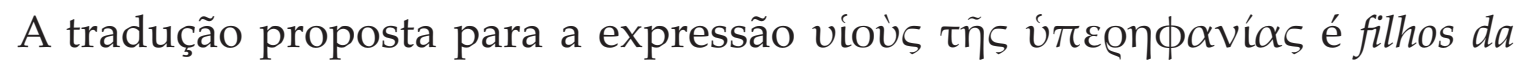
arrogância, ou como propõem Troiani e Balzaretti "figli dell'insolenza", filhos da insolência (2018, p. 65). A expressão soa estranha em português, tem um sentido pouco claro, mas é a reprodução literal do texto grego. Este tipo de tradução deveria ser rejeitado se a expressão víoù $\tau \tilde{\eta} \varsigma$ vं $\pi \varepsilon$ -

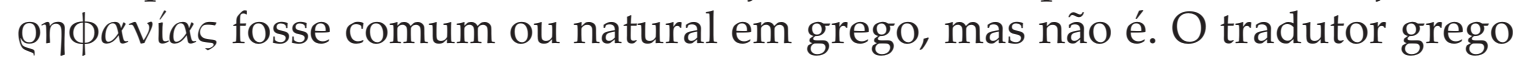
quis reproduzir em modo servil o hebraico, que usa a expressão "filho(s) de" para indicar um ou mais membros de uma categoria ou grupo de pessoas (KOEHLER; BAUMGARTNER, 2001, p. 138). Assim, o hebraico subjacente significaria simplesmente os arrogantes. Este tipo de expressão configura bom estilo em hebraico, é frequente e soa natural na suposta língua original do livro, mas não funciona tão bem em grego. $\mathrm{O}$ tradutor grego, no seu apego à literalidade, gerou uma estranheza na tradução que aqui é repetida na tradução da tradução. Assim, mesmo sendo possível recuperar o texto hebraico usado como base da tradução grega através de uma retroversão, a tradução em português se atém ao texto grego, não tem a pretensão de ir além da tradução grega mesma para corrigi-la ou melhorá-la. A consequência, no caso aqui descrito, é que o leitor da tradução portuguesa perceberá que algo parece fora de lugar, como acontece com o leitor do texto grego.

\subsection{A escolha do texto a ser traduzido}

Para que o trabalho de tradução possa começar, porém, o tradutor deve decidir o texto a ser utilizado como base para a tradução. À diferença das obras publicadas depois da invenção da imprensa, uma obra antiga muitas vezes só pode ser recuperada através do trabalho de reconstrução operado por especialistas em crítica textual. No caso de 1 Macabeus, o tradutor tem à disposição duas edições críticas do texto grego, aquela presente na edição manual de A. Rahlfs (RAHLFS, 2006), daqui por diante referida como LXX-Rahlfs, e aquela preparada no projeto da Septuaginta Unternehmen de Göttingen, o volume de W. Kappler para 1 Macabeus (KAPPLER, 1967), referida no presente artigo como LXX-Göttingen. Embora as divergências entre as duas edições não ocorram com muita frequência, em alguns casos o tradutor deve decidir qual das duas edições seguir e, assim, acaba tendo que trabalhar como crítico textual. Aqui, o tradutor deve não apenas confiar no trabalho de outros especialistas, mas também verificar os critérios aplicados nas respectivas edições críticas e cotejá-los com a opinião de outros comentadores. Para se chegar a uma decisão informada com relação a casos concretos, o tradutor precisará de noções sobre a situação dos manuscritos e da transmissão textual de 1 Macabeus, bem como da capacidade de manejar os critérios de crítica externa e interna em crítica textual. Como ressalta Aejmelaeus, nem sequer em uma tradução da Septuaginta se pode evitar completamente a tomada de decisões de crítica textual (AEJMELAEUS, 2007, p. 248). 
Um caso interessante é 1 Mc 2,10. Abaixo se veem os dois textos, segundo a edição de Rahlfs e aquela de Göttingen, seguidos das respectivas traduções:

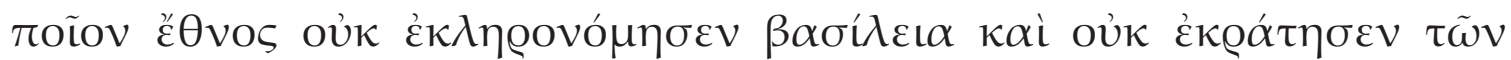

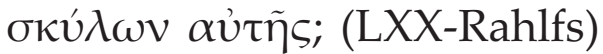

Qual nação não herdou seus palácios e não tomou os seus despojos?

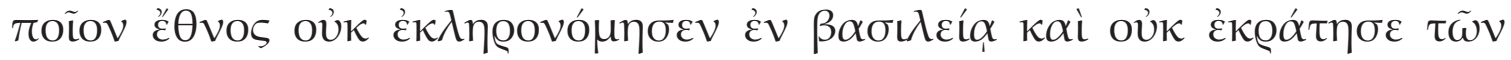

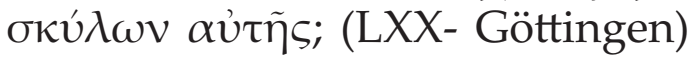

Qual nação não herdou seu reino e não tomou os seus despojos?

As duas edições divergem com relação às palavras, $\beta \alpha \sigma i ́ \lambda \varepsilon\llcorner\alpha$ na LXX-Rahlfs e èv $\beta \alpha \sigma \iota \lambda \varepsilon i ́ \alpha$ na LXX-Göttingen. No primeiro caso, se trataria do acusati-

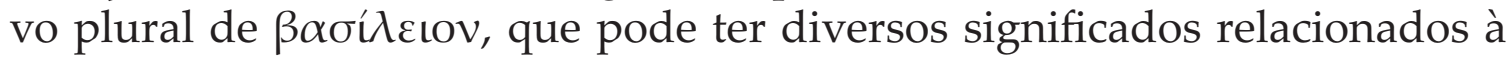
realeza como palácio, coroa, capital, tesouro ou efígie reais, enquanto no segundo se trataria do dativo singular de $\beta \alpha \sigma \iota \ell \varepsilon\{\alpha$, que pode significar reino, trono, soberania (RODRÍGUEZ ADRADOS; GANGUTIA, 1980, p. 688-689). A escolha tem implicações para a tradução e para o sentido do texto. Enquanto a palavra reino exprime em modo claro e direto o controle sobre o território e o governo de Israel, apossar-se dos palácios pode indicar a tomada do governo e, portanto, do controle político sobre Israel, mas o faz em modo indireto, através de uma figura de linguagem. Como fenômeno

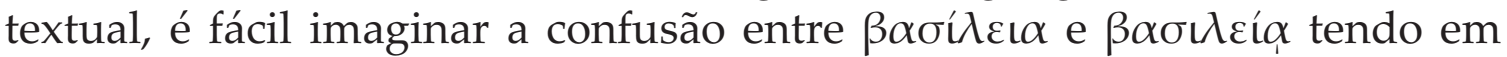
vista a grande semelhança entre as duas palavras e o fato de que ambas parecem ser adequadas ao contexto. A presença ou ausência da preposição $\dot{\varepsilon} V$ nas testemunhas textuais também pode ser facilmente relacionada a fenômenos típicos da transmissão manuscrita. Como a palavra precedente, $\varepsilon \dot{\varepsilon} \kappa \lambda \eta 0$ ó $\mu \eta \sigma \varepsilon v$, termina com as mesmas letras da preposição, a adição de $\dot{\varepsilon} v$ em alguns manuscritos pode ser atribuída a um caso de ditografia, ou seja, quando o escriba repete letras ou palavras por engano (TOV, 2017, p. 228). Contrariamente, caso a preposição seja parte do texto original, é possível explicar o seu desaparecimento em algumas testemunhas como um caso de haplografia, quando o escriba erroneamente escreve apenas uma vez letras ou palavras que se repetem (TOV, 2017, p. 225-226). Do ponto de vista das possibilidades, qualquer uma das variantes pode ter surgido a partir da sua concorrente por causa de um erro do escriba. Com relação à evidência das testemunhas textuais, enquanto a leitura čv $\beta \alpha \sigma i \lambda \varepsilon$ ć $_{1}$ é apoiada pelo Codex Sinaiticus, o texto Luciânico e a versão siríaca, a leitura $\beta \alpha \sigma i ́ \lambda \varepsilon \iota \alpha$ encontra suporte no Codex Alexandrinus, em um grande número de minúsculas e alguns dos melhores manuscritos das versões latinas. Também neste nível da análise é difícil decidir com segurança por uma das variantes, muito embora Goldstein dê mais peso para as testemunhas que atestam $\beta \alpha \sigma i ́ \lambda \varepsilon\llcorner\alpha$ (GOLDSTEIN, 1976, p. 232). Tilly prefere traduzir

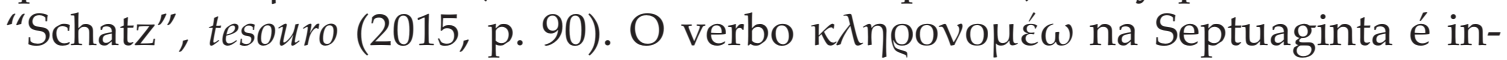
fluenciado pelos verbos hebraicos que comumente traduz e, assim, indica, como os correlativos hebraicos, não apenas herdar pacificamente, mas 
também a tomada de posse com violência (MURAOKA, 2009, p. 400). A coisa herdada ou possuída é comumente indicada apenas pelo acusativo em grego, o que levanta dúvidas sobre a preposição $\dot{\varepsilon} v$ seguida do dativo na leitura da LXX-Göttingen. Se, porém, o tradutor grego tinha diante de si o verbo hebraico נחל seguido da preposição $\exists$, significando tomada ou manutenção de posse como no Salmo 82,8 (KOEHLER; BAUMGARTNER, 2001, p. 686), a preposição غ̇v se explicaria como calco do hebraico. Como se vê, não é fácil chegar a uma decisão no caso presente. Em todo caso, o tradutor deve tomar uma decisão que determinará o sentido no texto traduzido. Em casos em que ambas as edições apresentam opções igualmente plausíveis e que não podem ser facilmente eliminadas pela aplicação de critérios de crítica textual nossa opção foi por seguir LXX-Göttingen.

Um outro exemplo de variante que altera o sentido do texto é encontrado em 1 Mc 2,8:

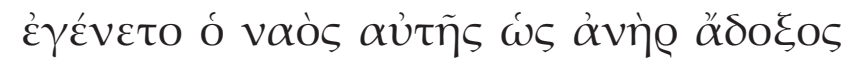

O seu Templo tornou-se como um homem desonrado.

Muito embora ambas as edições tenham escolhido a leitura vaós, santuário ou templo, algumas das testemunhas latinas contém $\lambda \alpha o$ ó, povo. Assim, teríamos a tradução: o seu povo tornou-se como um homem desonrado. Não é difícil imaginar como a confusão entre as duas palavras possa ter ocorrido durante o processo de cópia e transmissão do texto grego, sobretudo considerando que ambas as variantes oferecem um texto compreensível. Seria muito mais difícil uma confusão na fase da transmissão do latino entre populus e templum (CAÑAS REÍLLO, 2000, p. 110). Aqui deve-se aceitar a opção feita pelos editores, levando em consideração a atestação mais ampla da leitura voós (cf. TILLY, 2015, p. 90; TROIANI; BALZARETTI, 2018 p. 63), ao contrário do que preferiu Goldstein (1976, p. 231-232).

Um outro caso interessante, o qual comprova como o tradutor de um texto antigo precisa trabalhar também como crítico do texto, encontra-se em 1 Mc 10,49:

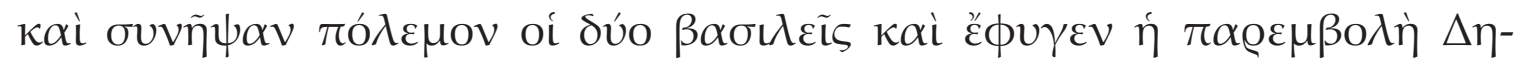

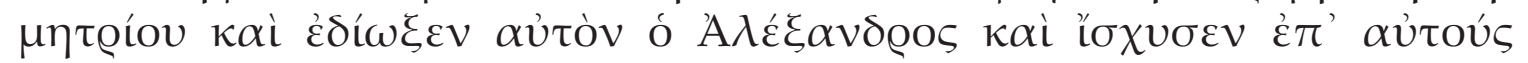
(LXX-Rahlfs)

Os dois reis travaram combate e o exército de Demétrio fugiu. Alexandre o perseguiu e prevaleceu sobre eles.

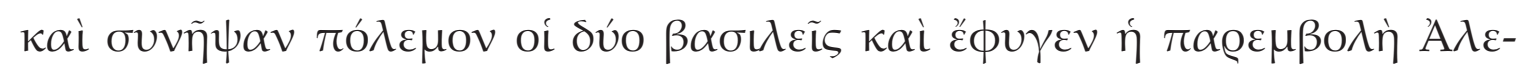

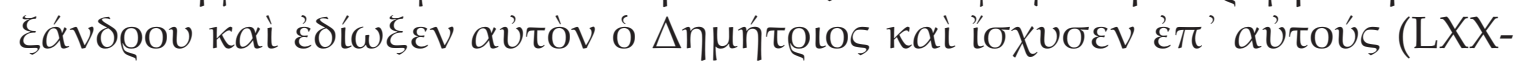
-Göttingen)

Os dois reis travaram combate e o exército de Alexandre fugiu. Demétrio o perseguiu, mas ele prevaleceu sobre eles. 
As duas edições divergem a respeito de qual exército teria fugido na batalha e qual exército teria saído em perseguição aos fugitivos. O motivo da diferença é que na própria tradição textual as testemunhas estão divididas. Como suporte da leitura da LXX-Göttingen temos Codex Alexandrinus e Codex Sinaiticus enquanto em favor da leitura da LXX-Rahlfs temos Codex Venetus, o texto Luciânico e a maioria das minúsculas e das testemunhas latinas. Embora um número superior de testemunhas textuais apoie a leitura da LXX-Rahlfs, aqui se pode invocar em favor da leitura da LXX-Göttingen um princípio muito importante em crítica textual, aquele da lectio difficilior. Este princípio sustenta que a leitura mais difícil no contexto é provavelmente a mais antiga ou original, pois a tendência ao longo da transmissão textual é a de tornar os textos mais compreensíveis, eliminando potenciais ambiguidades ou contradições (TOV, 2017, p. 279-281). Os escribas ou copistas, voluntária ou involuntariamente, tendem a criar leituras que resolvem as dificuldades e é mais provável que tenham adaptado o texto segundo uma certa lógica do que tenham criado uma contradição, sobretudo se a mudança é deliberada. Como se vê em 1 Mc 10,49, foram as tropas de Alexandre que venceram a batalha e Demétrio acaba morrendo no combate. Assim, um cenário em que o exército em fuga, no caso o de Alexandre, acaba prevalecendo na guerra é menos provável e mais difícil de se imaginar do que o contrário. Se encontramos neste texto uma facilitação ou uma tentativa de melhorar a sua lógica interna, é mais provável que um copista tenha, por assim dizer, colocado em fuga desde o início o exército perdedor, um cenário mais plausível. Goldstein argumenta da mesma maneira e explica que um copista pode não ter compreendido bem ou aceitado uma batalha com reviravoltas e, assim, teria alterado o texto para dizer que Demétrio perdia a batalha desde o início (1976, p. 414). A opção de Goldstein, Troiani e Balzaretti (2018, p. 114) e da LXX-Göttingen é provavelmente acertada, pois respeita os cânones fundamentais da crítica textual. Contudo, esta opção exige traduzir o último kaí do versículo como uma adversativa, ou seja, Demétrio o perseguiu, mas ele prevaleceu sobre eles. Neste caso, por ele o leitor deve entender Alexandre, graças à adversativa. Note-se que o pronome pessoal não é usado no texto grego, o que é bom estilo naquela língua, enquanto em português o pronome é usado com maior frequência e, portanto, aparece na tradução. Como explicado, Goldstein prefere ler com a LXX-Göttingen, ou seja, o exército de Alexandre teria fugido, mas como Alexandre sai vencedor na guerra, Goldstein compensa na sua tradução explicitando o sujeito do último verbo, Alexandre: "Demetrius pursued him, but Alexander's forces stiffened against his" (GOLDSTEIN, 1976, p. 403). Tilly, ao contrário, traduz "Demetrios verfolgte ihn und gewann die Oberhand", Demétrio o perseguiu e prevaleceu/levou vantagem (2015, p. 221), dando ao leitor a impressão de que Demétrio saíra vitorioso. Na nova tradução da CNBB a leitura da LXX-Göttingen foi adotada, mas, ao invés da adversativa 
no final do versículo, a tradução lê Demétrio partiu em sua perseguição e parecia estar vencendo (Bíblia Sagrada, 2018, p. 641), uma opção que resolve a dificuldade em modo curioso, embora pouco preciso.

\section{Correspondência formal}

Aqui veremos alguns casos concretos relacionados à busca de correspondência formal na tradução. Nem sempre é possível ao tradutor de um texto hebraico ao grego manter a correspondência formal entre expressões das duas línguas. Do mesmo modo, nem sempre é possível uma correspondência deste tipo entre expressões em língua grega e com aquelas em língua portuguesa.

Um dos critérios ou princípios de uma tradução mais literal é o da consistência na tradução, ou seja, a busca de uma correspondência entre um termo da língua de partida com um único termo da língua de chegada. Busca-se uma espécie de consistência no traduzir um termo da língua original pelo mesmo termo, sempre que possível, na língua de tradução (BARR, 1979, p. 294). Uma tradução portuguesa que busque, sempre que possível, este tipo de correspondência é, todavia, muitas vezes forçada a recorrer a termos variados em português, já que um único termo em português não poderia acomodar todos os significados abarcados pela palavra grega.

Assim, o termo Ěojov é usado várias vezes em 1 Mc. Já discutimos acima um problema em 1 Mc 2,47, mas vejamos como funciona o substantivo aqui:

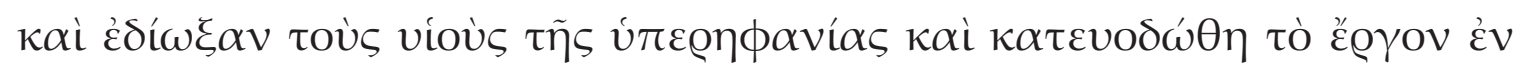
$\chi \varepsilon$ Łì $\alpha \hat{\tau} \tau \tilde{\omega} v$

Eles perseguiram os filhos da arrogância, a empresa prosperou em suas mãos

Matatias e seus companheiros reagem contra o jugo dos selêucidas e procuram restaurar a observância da lei em Israel, bem como eliminar a idolatria. A palavra ع̌ mas aqui se trata de uma ação sistemática com um propósito e o termo português empresa parece transmitir melhor a ideia do texto e do termo grego. A tradução italiana de Troiani e Balzaretti também opta por "impresa" (2018, p. 65). Na nova tradução da CNBB, encontramos a tradução campanha (Bíblia Sagrada, 2018, p. 623), uma escolha feliz do tradutor. O termo pode também ser traduzido como feito ou ação, mas estas são opções de tradução mais adequadas para 1 Mc 2,51:

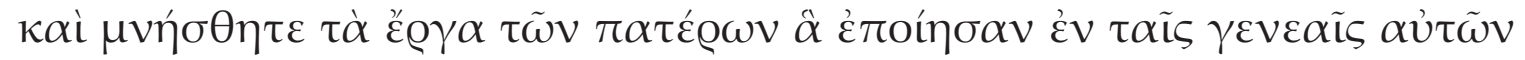
Recordai-vos dos feitos que nossos pais realizaram nas suas gerações

Matatias, em sua despedida, recomenda aos filhos que se lembrem das ações operadas pelos ancestrais do povo, os quais mencionará na sequência 
do texto (Abraão, José etc.). O plural $\tau \dot{\alpha}$ ع́ơ $\alpha$ designa as ações dos antepassados na fidelidade a Deus e na observância da lei, os grandes feitos ou ações de obediência aos mandamentos divinos, o objetivo central da rebelião conduzida por Matatias. Embora empresa não seja uma escolha inadequada (cf. TROIANI; BALZARETTI, 2018, p. 65), feitos é uma opção preferível. Em 2 Mc 3,4 a tradução feitos ou ações também é adequada, mas ali o feito não é tanto de fidelidade e observância da lei quanto ação ou feito militar, o que o leitor da tradução poderá inferir do contexto e das imagens evocadas pelo texto:

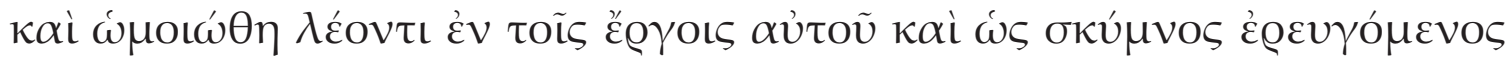

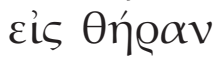

Era semelhante a um leão em suas ações, como um filhote de leão rugindo para a presa

O contexto fala da bravura de Judas Macabeu, descreve suas armas e a perseguição que levou a cabo contra os que não respeitavam a lei e confundiam o povo. A tradução façanhas na nova Bíblia da CNBB também constitui uma ótima escolha para o versículo (Bíblia Sagrada, 2018, p. 624). Interessante notar como em $1 \mathrm{Mc}$ a coragem para a ação militar possa ser descrita com o mesmo termo aplicado à perseverança e fidelidade a Deus no respeito e observância de sua lei.

Finalmente, a palavra em $1 \mathrm{Mc}$ pode significar obra no sentido de trabalho de construção civil. Assim, em 1 Mc 10,41 se lê:

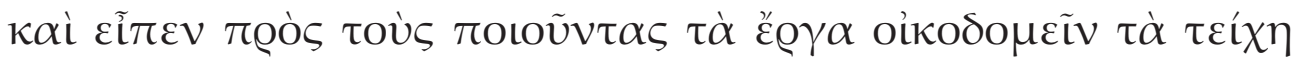

Ele disse aos que trabalhavam nas obras para construírem os muros

Aqui se trata da reconstrução de Jerusalém e de suas defesas por parte de

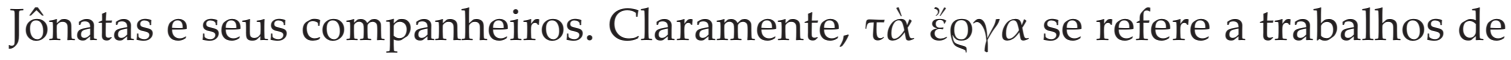
restauração e construção civil, e o termo obras parece ser o mais adequado (cf. TROIANI; BALZARETTI, 2018, p. 114). A Bíblia da CNBB aqui traduz simplesmente trabalhos (Bíblia Sagrada, 2018, p. 640).

Um outro exemplo muito claro desse fenômeno pode ser encontrado em 1 Mc 5,6:

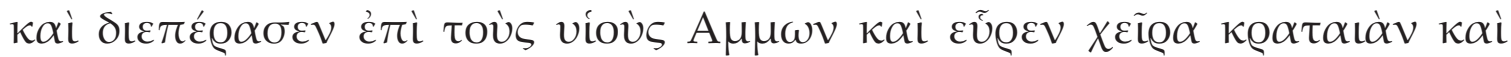

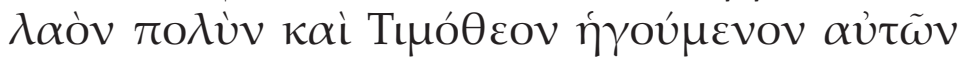

Depois atravessou para atacar os filhos de Amon. Encontrou um forte batalhão e muita gente, e Timóteo os conduzia

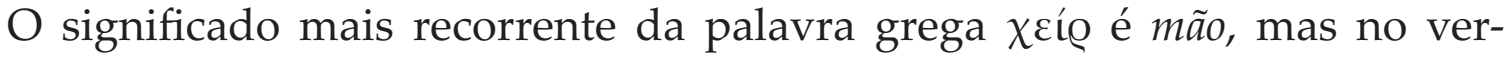
sículo em questão essa tradução não faria nenhum sentido. $O$ texto trata de movimentos de exércitos e tropas para a batalha e, no caso presente a palavra grega $\chi \varepsilon i ́$ se refere a uma unidade ou grupo organizado para 
um fim específico (MURAOKA, 2009, p. 730-731; LIDDELL; SCOTT, 1968, p. 1983-1984), ou seja, uma tropa ou batalhão. Trata-se de um uso mais raro do termo $\chi \varepsilon$ ć na tradução italiana "schiera", ou no alemão "Macht", exército (TROIANI; BALZARETTI, 2018, p. 79; TILLY, 2015, p. 140). A nova Bíblia da CNBB traduz exército (Bíblia Sagrada, 2018, p. 628). Assim, fica claro que uma excessiva consistência na tradução insistindo numa correspondência de um termo no original com um único termo em português acabaria produzindo um texto incompreensível, pois que sentido haveria dizer que ele (Judas) atravessou contra os filhos de Amon e encontrou uma "mão" forte?

Em todo caso, nos exemplos acima fica claro como um excessivo grau de consistência na tradução poderia levar a imprecisões e, como consequência, confundir o leitor. Assim, o tradutor precisa frequentemente optar por uma diversidade lexical superior àquela encontrada na língua de partida, mesmo quando o princípio da correspondência formal é deliberadamente buscado pelo mesmo tradutor.

O texto de 1 Mc 5,6 nos dá a oportunidade de discutir outros elementos de correspondência formal que criam problemas para uma tradução que quer ser mais literal e, ao mesmo tempo, compreensível. A tradução que persegue o princípio da correspondência formal procura reproduzir na tradução o mesmo número de elementos do texto original e até mesmo a categoria gramatical do termo traduzido (BARR, 1979, p. 303). Isso significa que o tradutor procuraria, por exemplo, traduzir três termos da língua original com três termos na língua de chegada, equivalência quantitativa. Se estes termos constituem um pronome, um verbo e um substantivo, as mesmas categorias gramaticais seriam buscadas na língua de chegada, equivalência formal. Embora difíceis de se manter, devido às diferenças entre grego e hebraico, se nota que em várias traduções na Septuaginta o tradutor procurou seguir estes princípios em graus variados. Como, porém, não é sempre possível ao tradutor grego respeitar estes princípios sem criar um texto absurdo, assim também não se pode passar do grego ao português com uma fidelidade absoluta a estas normas sem fazer violência

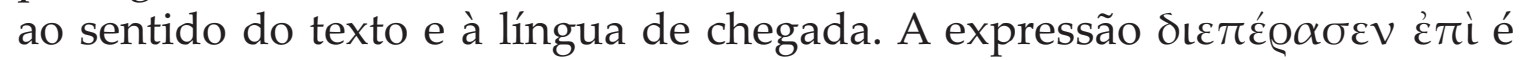
composta por um verbo e uma preposição, mas na tradução portuguesa aqui proposta lemos atravessou para atacar. Assim, dois elementos na língua de partida foram traduzidos com três elementos na língua de chegada, e ao invés de um verbo e uma preposição temos um verbo, uma preposição e outro verbo no infinitivo. Aqui, portanto, há um afastamento da equivalência quantitativa e da equivalência formal que em geral foi buscada ao longo da tradução. Por qual motivo? A preposição غ̇ंí provavelmente traduz o hebraico על, o qual, embora mais comumente signifique "acima" ou "sobre", frequentemente indica movimento hostil em direção a algo ou alguém. Uma tradução como atravessou sobre os filhos de Amon faria pouco sentido. Muraoka, no seu dicionário, também entende a expressão 
como movimento de atacar (MURAOKA, 2009, p. 156). Uma alternativa seria atravessou contra os filhos de Amon, a qual respeitaria as equivalências quantitativa e formal, e manteria o caráter em certa medida inusual da expressão. Goldstein percebeu essa nuance e traduz em inglês "crossing over against", enquanto Troiani e Balzaretti fazem o mesmo no italiano "e passò oltre contro i figli di Ammon" e Tilly no alemão "er zog gegen die Söhne Ammons" (GOLDSTEIN, 1976, p. 289; TROIANI; BALZARETTI, 2018, p. 79; TILLY, 2015, p. 140). A tradução atravessou para atacar é uma opção que privilegia a clareza, porém. Na nova Bíblia da CNBB esta nota de hostilidade não está presente na tradução, que lê passou depois para os amonitas (Bíblia Sagrada, 2018, p. 628).

Podemos mencionar neste versículo também uma questão interessante de sintaxe. Note-se que o grego kaí é repetido quatro vezes na passagem mencionada. O uso repetitivo de kaí no grego de 1 Mc é um dos sinais de que a obra se trata de uma tradução de um original semítico. Enquanto narrativas escritas originalmente em grego fazem uso de uma ampla variedade de partículas e preposições, no grego de tradução da Septuaginta

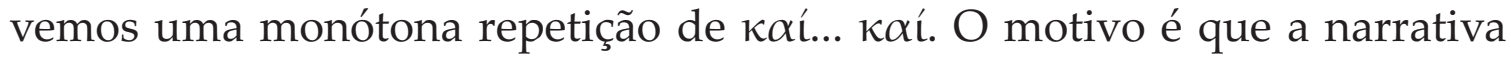
hebraica privilegia a coordenação entre períodos, ao contrário da narrativa grega que faz uso mais amplo da subordinação. Assim, o leitor grego de $1 \mathrm{Mc}$ se depara com uma sintaxe pouco natural e certamente pouco elegante na sua língua. Para se criar o mesmo efeito em português o tradutor deveria repetir indefinidamente e... e. O resultado, contudo, seria intragável. A necessidade mesma de pontuação para se limitar o tamanho dos períodos impõe que alguns kaí sejam traduzidos como pontos finais, às vezes como vírgulas. Outras vezes, se impõe a necessidade de marcar mais claramente que um evento acontece na sequência de um outro, e não concomitantemente. Assim, no versículo em questão o primeiro k $\alpha$ í foi traduzido como depois, explicitando a sequencialidade das ações, enquanto o segundo kaí foi traduzido como um ponto final. Muito embora a sequência $e \ldots e$ apareça na nossa tradução muito mais frequentemente do que em textos escritos em bom estilo em português, a monotonia dessa sintaxe foi atenuada na tradução.

Alguns hebraísmos presentes na tradução grega forçam o tradutor a decisões difíceis. Em 1 Mc 8,19, por exemplo, lemos:

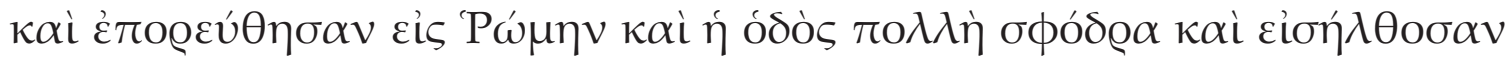

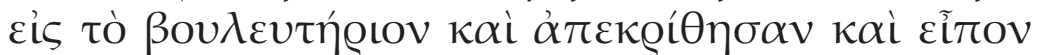

Eles foram a Roma, uma longa viagem, entraram no senado e disseram:

Uma primeira observação é que o pronome pessoal eles usado na tradução não tem correspondente no grego original. Em português a explicitação do sujeito com pronomes é mais frequente do que em grego, e aqui se trata apenas de adaptar estilo corrente e aceitável de uma língua para o estilo 
corrente de uma outra. Além disso, essa opção nos dá a possibilidade de nos desfazermos de mais uma repetição de kaí no início do versículo. $\mathrm{O}$

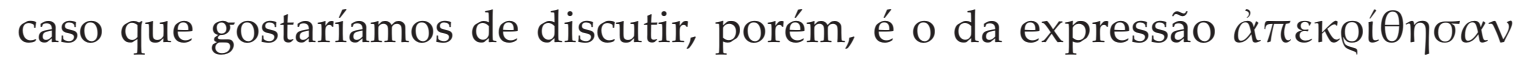

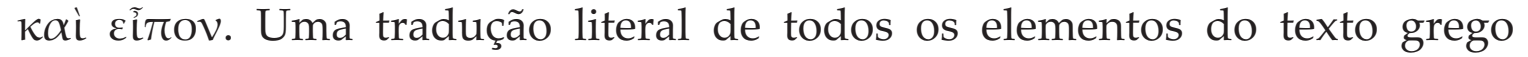
seria responderam e disseram. Como se entende do contexto, entretanto, não há nenhuma pergunta endereçada aos emissários de Judas, eles simplesmente entram no senado romano e começam a falar, apresentando sua proposta de aliança aos romanos. O texto grego reproduz um hebraísmo muito comum em prosa narrativa bíblica, um caso em que os dois verbos em hendíade significam simplesmente falaram ou declararam. O tradutor

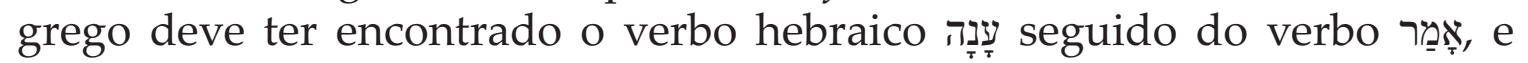
os reproduziu servilmente na tradução. Deveria o tradutor do português reproduzir a mesma estranheza presente no grego? Troiani e Balzaretti optaram por traduzir "e presero la parola e dissero", tomaram a palavra e disseram (2018, p. 89), enquanto Tilly traduz "sie erhoben die Stimme und sprachen", eles levantaram a voz e disseram (2015, p. 186). A opção feita na nova Bíblia da CNBB foi por traduzir e assim falaram (Bíblia Sagrada, 2018, p. 636). Na tradução proposta acima foi feita a opção por uma atenuação do caráter incomum da expressão também neste caso, assim se lê e disseram.

Um outro aspecto da correspondência formal diz respeito à ordem das palavras (WRIGHT, 1987, p. 311). O tradutor excessivamente literal procura sempre que possível respeitar a ordem dos elementos como aparecem no texto de partida da tradução. Línguas diferentes possuem regras diferentes com relação a essa ordem, daí que a reprodução da ordem da língua original pode gerar um efeito de artificialidade. O hebraico, por exemplo prefere a ordem Verbo-Sujeito enquanto na língua portuguesa a ordem direta prevê Sujeito-Verbo. No caso de $1 \mathrm{Mc}$, entre uma língua e a outra temos a intermediação da língua grega, que permite uma maior flexibilidade na ordem dos elementos do período. Vejamos a ordem das palavras num versículo já discutido acima, 1 Mc 10,49:

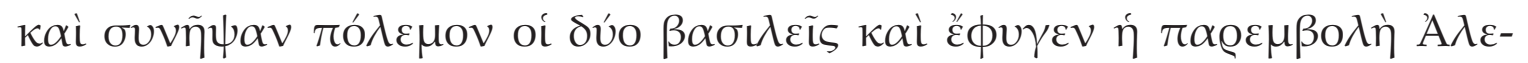

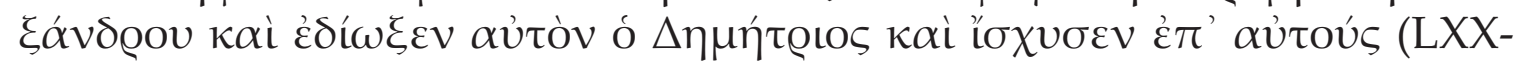
-Göttingen)

Os dois reis travaram combate e o exército de Alexandre fugiu. Demétrio o perseguiu, mas ele prevaleceu sobre eles.

Note-se que em todos os casos sublinhados a posição do sujeito no texto grego se encontra depois do verbo e, quando o verbo o requer, do seu objeto. Na tradução portuguesa proposta, a ordem das palavras é adaptada à ordem mais natural da língua portuguesa, já que não há propriamente artificialidade ou nada de incomum no texto grego mesmo. Assim, mais um aspecto da correspondência formal precisa ser frequentemente sacrificado, mesmo em uma tradução que pretende ser de cunho mais literal. Uma observação concernente à equivalência quantitativa, discutida acima, é que 
o artigo definido em ó $\Delta \eta \mu \eta ́ \tau$ ¡os não é reproduzido em português na tradução Demétrio, já que não se usa o artigo definido com nomes próprios na língua portuguesa, como pode ocorrer em grego.

\section{Ambiguidade na expressão grega}

Em alguns casos a expressão grega possui mais de um significado, ambos possíveis no contexto em que foram usadas, mas o tradutor acaba tendo que resolver a ambiguidade por não poder conservá-la na língua de chegada da tradução. Em 2 Mc 2,7, por exemplo, encontramos o seguinte texto:

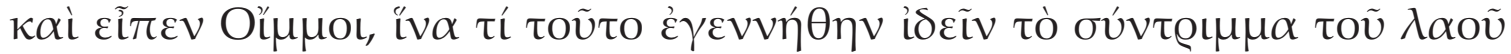

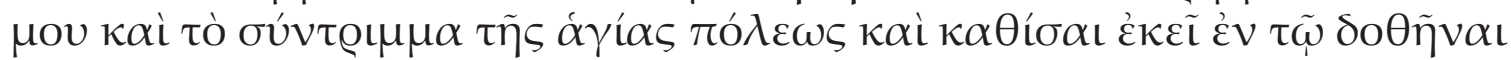

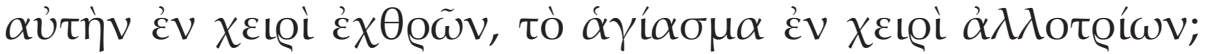

Ai de mim! Por que nasci para ver a destruição do meu povo e a destruição da cidade santa, e habitar lá enquanto ela foi entregue nas mãos dos inimigos, o santuário nas mãos dos estrangeiros?

O verbo $\kappa \alpha \theta i \zeta \omega$ pode significar aqui pelo menos duas coisas diversas. Ele pode ter o sentido de habitar, residir, morar ou o sentido de sentar-se (MURAOKA, 2009, p. 349-350). Se o tradutor faz a opção por habitar, entende-se que o verbo no infinitivo se refere a Matatias, que foi forçado a ver o sofrimento do seu povo e a violência contra Jerusalém enquanto ali habitava e antes de ir residir em Modin com sua família (1 Mc 2,1). Por outro lado, o tradutor que entende o verbo como sentar tende a ver aqui uma nuance de passividade, inação diante da violência perpetrada. Neste caso, os tradutores atribuem essa passividade ao povo e aos conformistas, e assim teríamos um texto como o da nova tradução da CNBB: todos ficaram sem ação enquanto ela era entregue às mãos dos inimigos (Bíblia Sagrada, 2018, p. 621). A noção de sentar-se quieto, sem reação, é também como Goldstein lê o versículo (1976, p. 231), mas também o italiano "stavano seduti" e o alemão "dort zu sitzen" (TROIANI; BALZARETTI, 2018, p. 63; TILLY, 2015, p. 90). A inação de parte da população e o seu colaboracionismo com os gregos selêucidas é parte do tema da obra. Assim, encontramos a questão da relação entre interpretação e tradução discutida por Umberto Eco na obra Dire quasi la stessa cosa: esperienze di traduzione (ECO, 2013). Propriamente, antes de traduzir e dar expressão na língua de chegada, o tradutor realiza uma operação de interpretação (ECO, 2013, p. 244-253). A tradução pressupõe interpretação e o tradutor não pode evadir questões relacionadas ao sentido da obra como um todo e do contexto próximo das expressões que deve traduzir. No caso presente, ao menos parte da ambiguidade do texto grego é perdida na tradução, não porque o tradutor queira eliminar a dúvida, mas porque esta não pode ser reproduzida na língua de chegada. A escolha por habitar aqui apresentada se deve ao fato 
de que em 1 Mc 2,1, pouco antes do caso em questão, o verbo $\kappa \alpha \theta i \zeta \omega$ foi usado para referir-se à mudança de residência de Matatias e sua família,

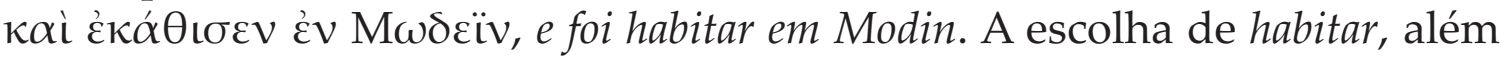
de ser provavelmente a melhor com relação ao sentido do texto do v. 7, conserva a repetição do mesmo verbo como acontece na língua de partida.

\section{Conclusão}

Traduzir uma tradução é uma tarefa que requer atenção a um conjunto muito especial de fatores. No caso de 1 Macabeus o propósito fundamental de realizar uma tradução que busque equivalência dinâmica exige a busca de uma certa correspondência formal, já que a obra mesma é uma tradução deste último tipo, mais tendente ao literalismo. Ao longo do trabalho, porém, o tradutor da língua moderna precisa contemporizar e ceder em muitos casos, como o fizera o tradutor grego séculos atrás. Fica claro, em todo caso, que as operações realizadas pelo tradutor são de natureza complexa, obrigando-o a lidar com questões de linguística envolvendo tanto a língua de partida quanto a língua de chegada da tradução. Além disso, o tradutor de um livro bíblico deve inevitavelmente trabalhar também como crítico textual e intérprete do texto a ser traduzido.

\section{Referências}

AEJMELAEUS, A. Translating a Translation: Problems of Modern "Daughter Versions" of the Septuagint". In: On the Trail of the Septuagint Translators: Collected Essays. Leuven: Peeters, 2007. p. 241-263.

BARR, J. The Typology of Literalism in Ancient Biblical Translations. Göttingen: Vandenhoeck \& Ruprecht, 1979.

BÍBLIA Sagrada. Tradução oficial da CNBB. Brasília: CNBB, 2018.

CAÑAS REÍLLO, J. M. (Ed.). Glosas marginales de Vetus Latina em Biblias Vulgatas españolas: 1-2 Macabeos. Madrid: CSIC, 2000.

ECO, U. Dire quasi la stessa cosa: Esperienze di traduzione. Milano: Bompiani, 2013.

GOLDSTEIN, J. A. I Maccabees: a New Translation with Introduction and Commentary by Jonathan A. Goldstein. Garden City, NY: Doubleday, 1976.

HARL, M. La "Bible d'Alexandrie" et les études sur la Septante: réflexions sur une première expérience. Vigiliae Christianae, Leiden, v. 47, n. 4, p. 313-340, 1993.

KAPPLER, W. (Ed.). Maccabaeorum liber I: Septuaginta Vetus Testamentum Graecum. 2. Durchgesehene Auflage. Göttingen: Vandenhoeck \& Ruprecht, 1967.

KOEHLER, L. H.; BAUMGARTNER, W. The Hebrew and Aramaic Lexicon of the Old Testament. Study Edition. Leiden: Brill, 2001. 
LIDDELL, H. G.; SCOTT, R. A Greek-English Lexicon: Revised and Augmented throughout by Sir Henry Stuart Jones with the Assistance of Roderick McKenzie and with Cooperation of many Scholars, with a Supplement. Oxford: Clarendon Press, 1968.

MURAOKA, T. A Greek-English Lexicon of the Septuagint. Leuven: Peeters, 2009.

NEUHAUS, G. O. Studien zu den poetischen Stücken im 1. Makkabäerbuch. Würzburg: Echter, 1974.

NIDA, E. A. Toward a Science of Translating: with Special Reference to Principles and Procedures Involved in Bible Translating. Leiden; Boston: Brill, 2003.

RAHLFS, A.; HANHART, R. (Ed.). Septuaginta: id est Vetus Testamentum graece iuxta LXX interpretes. Editio Altera. Stuttgart: Deutsche Bibelgesellschaft, 2006.

RODRÍGUEZ ADRADOS, F.; GANGUTIA, E. E. (Ed.). Diccionario griego-español. Redactado bajo la dirección de Francisco R. Adrados, por Elvira Gangutia et al. Madrid: CSIC, 1980.

TILLY, M. 1 Makkabäer: übersetzt und ausgelegt von Michael Tilly. Freiburg: Herder, 2015.

TILLY, M. Makkabaion I/Das Erste Buch Makkabaer. In: Handbuch zur Septuaginta: Einleitung in die Septuaginta. Gütersloh: Gütersloher Verlagshaus, 2016. p. 299-305.

TOV, E. Crítica textual da Bíblia Hebraica. Rio de Janeiro: BvBooks, 2017.

TROIANI, L.; BALZARETTI, C. 1-2 Maccabei: nuova versione, introduzione e commento di Lucio Troiani, Claudio Balzaretti. Milano: Paoline, 2018.

WRIGHT, B. G. The Quantitative Representation of Elements: Evaluating "Literalism" in the LXX". In: VI Congress of the International Organization for Septuagint and Cognate Studies, Jerusalem 1986. Atlanta: Scholars Press, 1987. p. 311-335.

Artigo submetido em 29.11.2020 e aprovado em 14.04.2020

Leonardo Pessoa da Silva Pinto é Doutor em Exegese Bíblica pelo Pontifício Instituto Bíblico (2019) e Professor Assistente da Faculdade Bíblica do Pontifício Instituto Bíblico para as áreas de crítica textual e exegese do Antigo Testamento. Orcid.org/0000-0001-5828-5430. E-mail: leoteopessoa@yahoo.com.br

Endereço: R. General Dionísio Cerqueira, 1004/402

Gutierrez

30441-058 Belo Horizonte - MG 